\title{
Endothelin-1 Transgenic Mice Develop Glomerulosclerosis, Interstitial Fibrosis, and Renal Cysts but Not Hypertension
}

\author{
Berthold Hocher, ${ }^{\ddagger}$ Christa Thöne-Reineke, ${ }^{\ddagger}$ Peter Rohmeiss, ${ }^{\S}$ Fred Schmager, $\|$ Torsten Slowinski, ${ }^{\star \ddagger}$ Volker Burst, ${ }^{\S}$ \\ Fred Siegmund, "Thomas Quertermous, " Christian Bauer, ${ }^{\ddagger}$ Hans-Hellmut Neumayer, ${ }^{*}$ Wolf-Dieter Schleuning, \\ and Franz Theuring\| \\ *Department of Nephrology, Charité, Humboldt University of Berlin, 10098 Berlin, Germany; ${ }^{\ddagger}$ Institute of Molecular Biology and \\ Biochemistry, Free University of Berlin, 14195 Berlin, Germany, ${ }^{\S}$ Department of Nephrology, Klinikum Mannheim, University of \\ Heidelberg, 68167 Mannheim, Germany; "Schering Research Laboratories Berlin, 13342 Berlin, Germany; and "Vanderbilt University, \\ Division of Cardiology, Nashville, Tennessee 37203
}

\begin{abstract}
The human endothelin-1 (ET-1) gene under the control of its natural promoter was transferred into the germline of mice. The transgene was expressed predominantly in the brain, lung, and kidney. Transgene expression was associated with a pathological phenotype manifested by signs such as age-dependent development of renal cysts, interstitial fibrosis of the kidneys, and glomerulosclerosis leading to a progressive decrease in glomerular filtration rate. This pathology developed in spite of only slightly elevated plasma and tissue ET-1 concentrations. Blood pressure was not affected even after the development of an impaired glomerular filtration rate. Therefore, these transgenic lines provide a new blood pressure-independent animal model of ET1-induced renal pathology leading to renal fibrosis and fatal kidney disease. (J. Clin. Invest. 1997. 99:1380-1389.) Key words: human endothelin-1 transgenic mice - renal cysts • glomerular filtration rate $\bullet$ glomerulosclerosis • blood pressure
\end{abstract}

\section{Introduction}

Apart from vasoconstriction, endothelins have been shown to cause a variety of biological activities in nonvascular tissues. For instance, the paracrine renal endothelin system is involved in the regulation of renal blood flow, glomerular filtration rate, and tubular water and sodium reabsorption (1-4). Furthermore, endothelin-1 (ET-1) ${ }^{1}$ is able to stimulate mesangial cell proliferation (5) and seems to be involved in matrix protein biosynthesis in the kidney (For review see reference 6). These findings evoke the possibility of an involvement of the paracrine endothelin system in the pathogenesis of glomerulosclerosis. Interestingly, several reports (7-9) demonstrate a corre-

Address correspondence to Franz Theuring, Universitätsklinikum Charité, Institut für Pharmakologie und Toxikologie, Dorotheenstr. 94, 10098 Berlin, Germany. Phone: +49-30-2093-4610; FAX: +49-302093-4615; E-mail: theuring@rz.charite.hu-berlin.de

Received for publication 30 July 1996 and accepted in revised form 15 November 1996.

1. Abbreviations used in this paper: ET-1, endothelin-1; PAS, periodic acid-Schiff; RT, reverse transcription.

J. Clin. Invest.

(C) The American Society for Clinical Investigation, Inc.

0021-9738/97/03/1380/10 \$2.00

Volume 99, Number 6, March 1997, 1380-1389 lation between glomerulonephritis/glomerulosclerosis and an activated renal endothelin system. However, it is still unknown whether an endogenous activation of the paracrine endothelin system is a cause or a consequence of glomerular injury. A powerful tool with which to answer this question will be an animal model with primary activated paracrine endothelin system in which no other stimuli can contribute to renal injury. We therefore generated human ET-1 transgenic mice. Transgene expression was analyzed by Northern blot analysis and in situ hybridization. Since the pathological phenotype of these mice exhibited renal cysts, interstitial fibrosis, and glomerulosclerosis, we also analyzed the glomerular filtration rate and blood pressure as well as potassium, sodium, and protein excretion.

\section{Methods}

Materials. Unless otherwise stated, all reagents were of analytical grade and were purchased from Merck (Darmstadt, Germany), Boehringer Mannheim (Mannheim, Germany), or Sigma Chemical Co. (Munich, Germany). All animal experiments were conducted in accordance with local institutional guidelines for the care and use of laboratory animals. The mice were kept under controlled environmental conditions with respect to temperature $\left(20^{\circ} \mathrm{C}\right)$, humidity (64\%), and night-day cycle (light period: 0600-1800). The mice received tap water and a standard mouse diet.

Generation and identification of human ET-1 transgenic mice. Transgene construction. A human genomic lambdaphage library constructed in EMBL3 with DNA isolated from peripherial blood lymphocytes was screened with a genomic human ET-1 cDNA probe as described by Bloch et al. (10). One 16-kD clone isolated in this fashion contained the entire human ET- 1 gene including $\sim 8 \mathrm{~kb}$ of $5^{\prime}$ flanking sequence and $\sim 1.5 \mathrm{~kb}$ of $3^{\prime}$ flanking sequences. This fragment was subcloned into pGEM 3 and used for microinjection.

Microinjection. Transgenic mice were generated as recently described with minor modifications (11). Briefly, human ET-1 transgenic mice were produced by microinjection of linear human ET-1 genomic DNA fragments into one-cell embryos obtained from hormone-primed NMRI females mated the night before injection with NMRI males. After microinjection, viable eggs were transferred to the oviducts of pseudopregnant NMRI mice. Transgenic mice were identified by both Southern blot analysis (11) and PCR of DNA isolated from tail biopsies using human ET-1-specific primers (sense: $5^{\prime}$ TGA GGA CAT GTT GGT CCT GA 3'; antisense 5' AGC GAC AGG TCC ATA ATG AC $\left.3^{\prime}\right)$.

Reverse transcription-PCR. Expression analysis in transgenic mice was performed by reverse transcription (RT)-PCR. RNA was prepared using TRIzol reagent (GIBCO BRL, Gaithersburg, MD). RNA samples were reverse transcribed (M-MLV Reverse Trancriptase; GIBCO BRL), and the resultant cDNA was amplified by a PCR with specific human ET-1 primers as described by Bloch et al. (10): sense: 5' TCC AGA GAG CGT TAT GTG AC 3'; antisense: 5' 
TTC TGC TGA GAG CAT TG $3^{\prime}$. After pretreatment $\left(94^{\circ} \mathrm{C}, 5\right.$ min), a step program $\left(58^{\circ} \mathrm{C}, 60 \mathrm{~s} ; 72^{\circ} \mathrm{C}, 75 \mathrm{~s} ; 94^{\circ} \mathrm{C}, 60 \mathrm{~s} ; 28\right.$ cycles $)$ was performed, followed by a final extension reaction $\left(72^{\circ} \mathrm{C}, 10 \mathrm{~min}\right)$.

Northern blot. Total RNA was extracted from frozen tissues, separated electrophoretically on a formamide/formaldehyde-agarose gel and blotted as described recently (11). After prehybridization, the membranes were hybridized with ${ }^{32} \mathrm{P}$-dATP-labeled cDNA probes. We used a specific human ET-1 fragment as described by Bloch et al. (10) and a rat $\beta$-actin fragment. The fragments were labeled with ${ }^{32} \mathrm{P}$-dATP by the random priming method. Blots were washed under high stringency conditions. Autoradiography was performed at $-80^{\circ} \mathrm{C}$. $\beta$-Actin was used as internal standard.

In situ hybridization. We used a 1.2-kb Eco R1 human ET-1 fragment (10) subcloned in pBluescript 2+ SK plasmid (Stratagene, Inc., La Jolla, CA) and a $0.5-\mathrm{kb}$ rat actin fragment subcloned in pGem $7 \mathrm{Z}$ as control. The plasmids were linearized with either Kpn 1 or Sst 2 . Single-stranded RNA probes, complementary (antisense probe) or anticomplementary (sense probe, negative control) to cellular RNA, were obtained by run-off transcription with T7 or T3 RNA polymerase (Transcription Kit; Boehringer Mannheim). ${ }^{35} \mathrm{~S}-\mathrm{UTP}$ was used for labeling the RNA probes. The specific activity of the probes was $1.0-1.5 \times 10^{9} \mathrm{cpm} / \mathrm{mg}$ RNA.

Prehybridization, hybridization, washing, and RNase A digestion to remove nonspecifically bound probes as well as autoradiography were performed as described (4) with modifications. The tissue sections (cryostat sections, $5 \mu \mathrm{m}$, on siliconized slides) were treated with $0.2 \mathrm{~mol} /$ liter $\mathrm{HCl}$ for $20 \mathrm{~min}$, digested in $0.125 \mathrm{mg} / \mathrm{ml}$ pronase (Boehringer-Mannheim) for $10 \mathrm{~min}$ at $22^{\circ} \mathrm{C}$, rinsed in $0.1 \mathrm{~mol} / \mathrm{liter}$ glycine/ PBS, washed in PBS, fixed again in $4 \%$ phosphonoformatic acid/PBS for $15 \mathrm{~min}$, acetylated in a solution of acetic anhydride $/ 0.1 \mathrm{~mol} / \mathrm{liter}$ triethanolamine, $\mathrm{pH} 8.0$ (dilution 1:400), rinsed again in PBS, dehydrated in graded ethanol, and air dried. Each slide was covered with $0.025 \mathrm{ml}$ of hybridization mixture containing $2.5 \times 10^{5} \mathrm{cpm}$ of labeled RNA probe in $50 \%$ formamide, $10 \%$ dextran sulphate, $10 \mathrm{mmol} / \mathrm{liter}$ DTT, $10 \mathrm{mmol} /$ liter Tris-HCl, pH 7.5, $10 \mathrm{mmol} /$ liter $\mathrm{Na}_{2} \mathrm{HPO}_{4}, 0.3$ $\mathrm{mol} / \mathrm{liter} \mathrm{NaCl}, 5 \mathrm{mmol} / \mathrm{liter}$ EDTA, $0.2 \mathrm{mg} / \mathrm{ml}$ yeast tRNA. Sections were sealed with a siliconized coverslip. After $20 \mathrm{~h}$ of incubation at $50^{\circ} \mathrm{C}$ in a humid chamber, slides were washed for $4 \mathrm{~h}$ at $50^{\circ} \mathrm{C}$ in a solution of $50 \%$ formamide, $10 \mathrm{mmol} /$ liter DTT, $1 \times$ SALTS, and for 15 $\mathrm{min}$ in $10 \mathrm{mmol} / \mathrm{liter}$ Tris-HCl, $\mathrm{pH} 7.5,0.5 \mathrm{~mol} / \mathrm{liter} \mathrm{NaCl}, 1 \mathrm{mmol} / \mathrm{li}-$ ter EDTA at $37^{\circ} \mathrm{C}$, and then digested with RNAse A to reduce background caused by nonspecific binding, washed again in $10 \mathrm{mmol} /$ liter Tris-HCl, $\mathrm{pH} 7.5,0.5 \mathrm{~mol} / \mathrm{liter} \mathrm{NaCl}, 1 \mathrm{mmol} / \mathrm{liter}$ EDTA (TES) for $30 \mathrm{~min}$, and finally rinsed in $2 \times \mathrm{SSC}, 0.1 \times \mathrm{SSC}$, and $0.05 \times \mathrm{SSC}$ for 20 min each at $22^{\circ} \mathrm{C}$. The slides were dehydrated in graded ethanol, air dried, and dipped in Ilford K5 photoemulsion (Ilford Mobberley, Cheshire, UK). After exposure for $10-28 \mathrm{~d}$ at $4^{\circ} \mathrm{C}$, sections were developed for 2.5 min using the D 19 developer (Eastman Kodak Co., Hemel Hampstead, UK), subsequently rinsed in $1 \%$ acetic acid, fixed in Kodak fixer for $2.5 \mathrm{~min}$, washed in $\mathrm{H}_{2} \mathrm{O}$, and counterstained by hematoxylin-eosin. All tissues were simultaneously processed using the same probes and reagents ( $n=6$ in each group). Sense and antisense human ET-1-mRNA probes were used in each experiment.

Endothelin radioimmunoassay. ET-1 was extracted from tissue as described recently (12). Immunoreactive ET-1 was measured using a commercial endothelin [ $\left.{ }^{125} \mathrm{I}\right]$ radioimmunoassay kit (Endothelin-1,2, high sensitivity, $\left[{ }^{125} \mathrm{I}\right]$ assay system; Amersham International, Little Chalfont, UK) according to the instructions given by the manufacturer. This assay reacts $100 \%$ with ET- 1 and cross-reacts 1,307\% with ET-2. Cross-reactivity with ET-3 was $<0.001 \%$.

Histological evaluation. For pathohistological evaluation, all samples were submitted to hematoxylin-eosin, Masson-Trichrome, and periodic acid-Schiff (PAS) staining. The number of renal cysts in transgenic mice and nontransgenic littermates were counted in corresponding cross sections. Glomerular volume, glomerular cell density, and media/lumen ratio of the aorta and intrarenal arteries was analyzed using a video microscope connected to a personal computer. The data thus obtained were analyzed using the Image 1.5 program.
The extent of glomerulosclerosis was analyzed according to Raij et al. (13). Glomerulosclerosis was defined by the presence of increased amounts of PAS positive material within the glomeruli. To consider differences in the degree of glomerulosclerosis, a semiquantitative score was used. A minimum of 80 glomeruli in each specimen was examined and the degree of lesion was graded from 0 to $4+$ according to the percentage of glomerular involvement. Thus a $1+\mathrm{le}-$ sion represented an involvement of $25 \%$ of the glomerulus, while a $4+$ lesion indicated that $100 \%$ of the glomerulus was PAS positive. All tissue samples were evaluated independently by two investigators without prior knowledge of the group to which the mice belonged.

The severity of interstitial matrix deposition was evaluated after Masson-Trichrome staining (14) using an image analyzing system (Quantimed 600; Leica, Benzheim, Germany). We measured the relationship of green stained interstitial area (connective tissue) to total interstitial area of the whole kidney section.

Serum and urine analysis. Serum and urine levels of potassium, sodium, creatinine, and protein were determined using the appropriate kits (jaffé method for creatinine and biuret method for protein) in an automatic analyzer. The mice were kept under controlled environmental conditions with respect to temperature $\left(20^{\circ} \mathrm{C}\right)$, humidity (64\%), and night-day cycle (light period: 0600-1400). The mice received tap water and a standard mouse diet. Water, potassium, and sodium intake were controlled during the whole experiment.

The absolute excretion of either sodium or potassium was calculated by the equation: $\mathrm{Ux} \times \mathrm{V} 24$, where $\mathrm{Ux}$ is the concentration of either sodium, protein, or potassium and V24 is the amount of urine excreted in $24 \mathrm{~h}$.

Measurement of blood pressure and glomerular filtration rate. The mice were anesthetized with thiobutabarbital $(20 \mathrm{mg} / 100 \mathrm{~g})$ and ketamine $(20 \mathrm{mg} / 100 \mathrm{~g})$. Animals were placed on a heating table and a tracheotomy was performed. A teflon catheter connected to a polyethylene catheter was inserted into the right femoral artery with the tip of the teflon catheter positioned at the aortic bifurcation for measurement of arterial blood pressure and heart rate (HR). A second catheter was inserted into the right femoral vein. For urine collection, a polyethylene catheter was inserted through a suprapubic incision into the urinary bladder. The arterial catheter was connected to an electromagnetic pressure transducer. BP signals were transmitted to a blood pressure amplifier that allowed measurement of HR, systolic, diastolic, and mean arterial blood pressure. The endogenous creatinine clearance was calculated using the formula $\mathrm{C}=\mathrm{Uc} \times \mathrm{Uvol} / \mathrm{Sc}$ where $\mathrm{C}$ is creatinine clearance, $\mathrm{Uc}$ is urinary creatinine concentration, Uvol is urine volume, and $\mathrm{Sc}$ is serum creatinine concentration.

To replace fluid losses, a continuous infusion of isotonic saline $(180 \mu \mathrm{l})$ was commenced. Blood pressure and heart rate were recorded continuously and analyzed after a stable baseline of the above mentioned parameters had been achieved. Only those animals were included in the study that had blood pressure variations $<8 \%$ and heart rate variations $<15 \%$ during the whole collecting period. Samples of urine were collected over a period of $3 \mathrm{~h}$ after equilibration of hemodynamic parameters. Blood samples $(100 \mu \mathrm{l})$ were taken at the end of that period.

We analyzed six groups for blood pressure, heart rate, and creatinine clearance. $n$ was 7-9 in each group. Group 1: 3-mo-old nontransgenic male littermates; group 2: 3-mo-old heterozygous transgenic male mice, line 238; group 3: 3-mo-old heterozygous transgenic male mice, line 856; group 4: 14-mo-old nontransgenic male littermates; group 5: 14-mo-old heterozygous transgenic male mice, line 238; Group 6: 14-mo-old heterozygous transgenic male mice, line 856.

\section{Results}

Three independent transgenic lines were established (lines 238, 260, and 856). Transgene carrier status was assessed by Southern blotting and PCR of tail biopsies. Lines 238 and 856 were selected for further analysis. Due to the small number of homozygous transgenic mice, no statistical analysis was possi- 

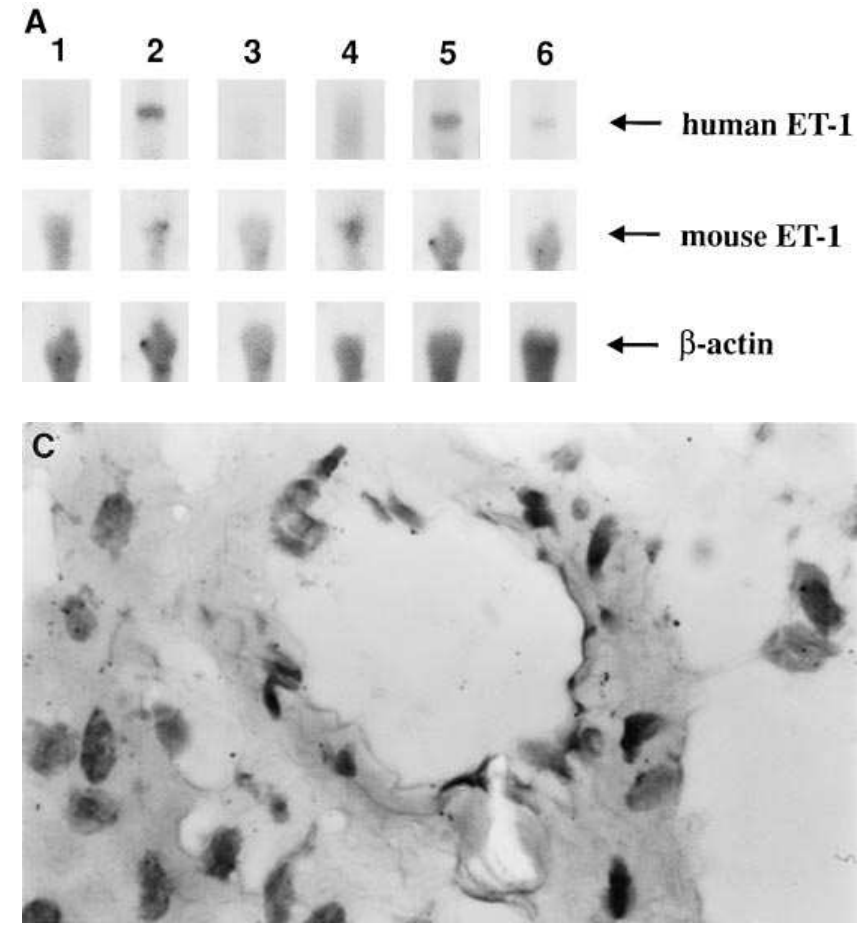

ble. However, the phenotype in these animals was qualitatively similar to the findings in heterozygous transgenic mice. No additional phenotypic, toxic, or functional alterations were detectable compared with heterozygous transgenic mice (data not shown).

\section{Expression of the human ET-1 gene}

Northern blotting. Transgene expression was seen by Northern blot analysis in the brain, lungs, and kidneys of both transgenic mice lines (lines 238 and 856) in equal amounts (Fig. 1 shows transgene expression in line 856). The transcription level of $\beta$-actin was similar in transgenic and nontransgenic mice. Using the more sensitive RT-PCR with human-specific ET-1 primers, lower levels of transgene expression were also detectable in the heart, liver, salvary gland, spleen, and testis (data not shown). Transgene expression was not detectable in nontransgenic littermates.

In situ hybridization. For the cellular localization of ET-1 mRNA in human ET-1 transgenic mice, in situ hybridization

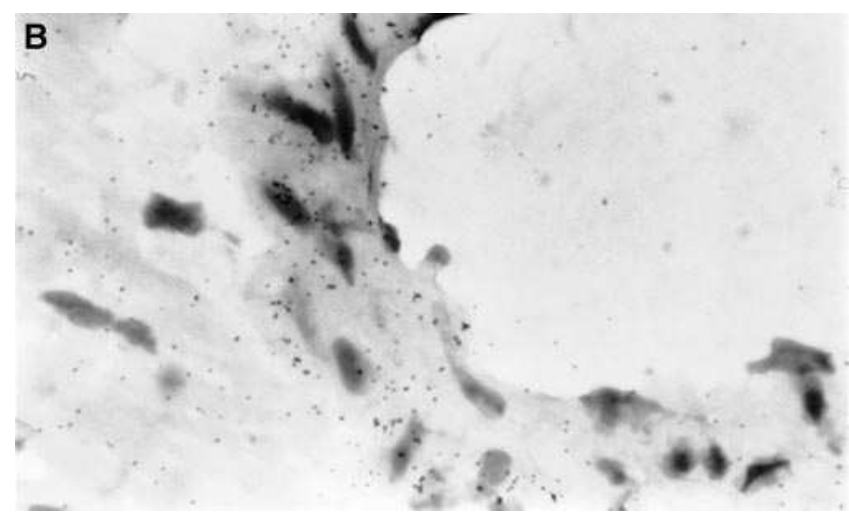

Figure 1. (A) A representative Northern blot analysis demonstrating the expression of human and mouse preproendothelin- 1 and $\beta$-actin mRNA in heterozygous human ET-1 transgenic mouse (line 856) is shown. (1, heart; 2 , kidney; 3 , liver; 4 , spleen; 5, lung; 6 , brain). (B) In situ hybridization showing vascular ET-1 mRNA expression in smooth muscle cells of a 14-mo-old heterozygous human ET-1 transgenic mouse (line 856) using a human ET-1 mRNA antisense probe. (C) Control in situ hybridization with a ${ }^{35}$ S-labeled human ET-1 mRNA sense probe.

technique was used. The specific hybridization of each probe under our experimental conditions was confirmed by a very low hybridization signal in parallel experiments using sense probes (Fig. $1 C$ ). The human ET-1 mRNA was located in the glomeruli, renal tubules, and blood vessels. The transgene expression pattern was equal in both human ET-1 transgenic mice lines. No qualitative or quantitative differences concerning renal transgene expression were detected. The ET-1 signals in the blood vessels were located on the smooth muscle cells (Fig. $1 \mathrm{~B}$ ). Due to the sequence homology of the murine and human ET-1 gene, low levels of specific ET-1 mRNA expression were also seen in nontransgenic littermates using the human ET-1 mRNA antisense probe.

\section{Plasma and tissue concentrations of ET-1}

Plasma levels of ET-1 were elevated $\sim 35 \%$ in 3- and 14-moold heterozygous animals of lines 238 and 856, respectively, which was not significant (Table I). Examination of tissue levels, on the other hand, revealed significantly increased total

Table I. Plasma and Tissue ET-1 Concentrations in 3- and 14-mo-old Heterozygous Human ET-1 Transgenic Mice and Age-matched Controls

\begin{tabular}{|c|c|c|c|c|c|c|}
\hline & $\begin{array}{l}\text { 3-mo-old controls } \\
\quad(n=6)\end{array}$ & $\begin{array}{c}\text { 3-mo-old } \\
\text { ET-1 tg mice, } \\
\text { line } 238 \\
(n=6)\end{array}$ & $\begin{array}{l}\text { 3-mo-old } \\
\text { ET-1 tg mice, } \\
\text { line } 856 \\
(n=6)\end{array}$ & $\begin{array}{l}\text { 14-mo-old controls } \\
\quad(n=8)\end{array}$ & $\begin{array}{l}\text { 14-mo-old } \\
\text { ET-1 tg mice, } \\
\text { line } 238 \\
(n=8)\end{array}$ & $\begin{array}{c}\text { 14-mo-old } \\
\text { ET-1 tg mice } \\
\text { line } 856 \\
(n=8)\end{array}$ \\
\hline Plasma ET-1 (pg/ml) & $14.4 \pm 3.6$ & $18.6 \pm 3.9$ & $19.5 \pm 4.1$ & $15.3 \pm 5.1$ & $20.6 \pm 4.7$ & $21.8 \pm 3.9$ \\
\hline Kidney tissue ET-1 (pg/g wet wt) & $31.6 \pm 4.3$ & $48.2 \pm 5.1 *$ & $51.6 \pm 5.9 *$ & $37.6 \pm 5.1$ & $39.2 \pm 10.7$ & $46.9 \pm 9.1$ \\
\hline
\end{tabular}

Values are means $\pm \mathrm{SD} ;{ }^{*} P<0.05$ for $t$ test compared with age-matched controls; $\operatorname{tg}$, transgenic. 
Table II. Body Growth, Kidney and Heart Weight, Glomerular Volume, Glomeruli/Kidney Section, and Glomerular Cell Density in 3- and 14-mo-old Heterozygous Human ET-1 Transgenic Mice and Age-matched Controls

\begin{tabular}{|c|c|c|c|c|c|c|}
\hline & $\begin{array}{l}\text { 3-mo-old controls } \\
\quad(n=6)\end{array}$ & $\begin{array}{l}\text { 3-mo-old } \\
\text { ET-1 tg mice, } \\
\text { line } 238 \\
(n=6)\end{array}$ & $\begin{array}{l}\text { 3-mo-old } \\
\text { ET-1 tg mice, } \\
\text { line } 856 \\
(n=6)\end{array}$ & $\begin{array}{c}\text { 14-mo-old controls } \\
(n=8)\end{array}$ & $\begin{array}{l}\text { 14-mo-old } \\
\text { ET-1 tg mice, } \\
\text { line } 238 \\
(n=15)\end{array}$ & $\begin{array}{l}\text { 14-mo-old } \\
\text { ET-1 tg mice, } \\
\text { line } 856 \\
(n=8)\end{array}$ \\
\hline Body weight & $41.6 \pm 2.9$ & $40.3 \pm 1.6$ & $41.2 \pm 2.3$ & $47.9 \pm 4.0$ & $50.6 \pm 5.7$ & $45.7 \pm 5.5$ \\
\hline Kidney weight & $0.30 \pm 0.04$ & $0.30 \pm 0.02$ & $0.31 \pm 0.05$ & $0.36 \pm 0.1$ & $0.46 \pm 0.07$ & $0.40 \pm 0.09$ \\
\hline Kidney/body weight $(\% / 00)$ & $7.0 \pm 0.34$ & $6.5 \pm 0.70$ & $7.5 \pm 0.84$ & $7.5 \pm 0.8$ & $9.1 \pm 1.1$ & $8.8 \pm 1.0$ \\
\hline Glomerular area $\left(\mu \mathrm{m}^{2}\right)$ & $4450 \pm 1440$ & $6255 \pm 2499 *$ & $4005 \pm 1349$ & $5232 \pm 1708$ & $5963 \pm 2185$ & $4623 \pm 1340$ \\
\hline Glomerular cell density (cells/1,000 $\mu \mathrm{m}^{2}$ ) & $7.38 \pm 1.09$ & $6.47 \pm 0.70^{*}$ & $6.61 \pm 0.71 *$ & $9.73 \pm 1.11$ & $10.00 \pm 1.84$ & $11.00 \pm 1.05^{*}$ \\
\hline Glomeruli/10 mm² kidney section $(n)$ & $30.67 \pm 2.68$ & $24.06 \pm 3.48 *$ & $26.06 \pm 3.99$ & $32.97 \pm 3.77$ & $25.93 \pm 1.82 *$ & $29.62 \pm 3.34$ \\
\hline Heart weight & $0.20 \pm 0.02$ & $0.20 \pm 0.016$ & $0.21 \pm 0.016$ & $0.24 \pm 0.03$ & $0.294 \pm 0.04$ & $0.30 \pm 0.034$ \\
\hline Heart/body weight $(\% / 00)$ & $6.0 \pm 0.40$ & $5.0 \pm 0.27$ & $5.1 \pm 0.37$ & $5.0 \pm 0.5$ & $5.8 \pm 0.9$ & $6.7 \pm 0.5^{\ddagger}$ \\
\hline Media/lumen ratio of intrarenal arteries & $1.64 \pm 0.58$ & $1.85 \pm 0.74$ & $1.95 \pm 0.61$ & $1.52 \pm 0.70$ & $1.76 \pm 0.74$ & $2.10 \pm 0.39 *$ \\
\hline Media/lumen ratio of the aorta & - & - & - & $1.01 \pm 0.47$ & $1.12 \pm 0.52$ & $1.71 \pm 1.11$ \\
\hline
\end{tabular}

Body and organ weights are given in grams. $n=8$ in each group. Values are means $\pm \mathrm{SD} ;{ }^{*} P<0.05$ for $t$ test compared with age-matched controls; ${ }^{\ddagger} P<0.01$ for $t$ test compared with age-matched controls; tg, transgenic.

kidney tissue immunoreactive ET-1 concentrations in both lines compared with nontransgenic littermates at 3 mo. The renal tissue ET-1 concentrations in 14-mo-old transgenic mice were not significantly elevated (Table I).

Body size, heart and kidney weight, urine sodium, potassium, and protein excretion

At 3 and 14 mo, there were no significant differences in body weight between heterozygous human ET-1 transgenic mice and age-matched controls (Table II). The kidney/body weight ratio in 3-mo-old mice was similar, while the kidney/body weight ratio in 14-mo-old human ET-1 transgenic mice was $21 \%$ (line 238) and 13\% (line 856) higher than in control mice. The heart/body weight ratio in 14-mo-old human ET-1 transgenic mice (line 856) was significantly increased compared with age-matched controls. ET-1 transgenic mice of line 238, on the other hand, showed only a nonsignificant tendency towards increased heart/body weight ratio (Table II). Total urinary potassium and protein excretion were similar in 14-mo-old human ET-1 transgenic mice compared with age-matched controls. The daily urine sodium excretion was significantly reduced in ET-1 transgenic mice of line 238, while transgenic mice of line 856 had a small nonsignificant reduction of sodium excretion (Table III).

Since we found reduction of urinary sodium excretion only in one transgenic mice line, we do not assume that this is an effect of transgene overexpression. Due to well known nonspecific integration phenomena in transgenic animal models, phenotypic alterations are only considered to be induced by the overexpression of the transgene (ET-1 in this case), if these alterations are detectable independently in different transgenic lines. It is therefore more likely that the reduced sodium excretion seen only in line 238 is due to a nonspecific integration phenomena of the transgene.

Glomerulosclerosis, interstitial fibrosis, renal cysts, and medial lumen ratio of intrarenal arteries

The 14-mo-old ET-1 transgenic mice had a significantly increased amount of PAS positive material within the glomeruli

Table III. Renal Protein, Potassium, and Sodium Excretion in 14-mo-old Male Heterozygous Human ET-1 Transgenic Mice and Age-matched Controls

\begin{tabular}{|c|c|c|c|}
\hline & $\begin{array}{c}\text { 14-mo-old controls } \\
(n=10)\end{array}$ & $\begin{array}{l}\text { 14-mo-old ET-1 tg mice, } \\
\text { line } 238(n=10)\end{array}$ & $\begin{array}{l}\text { 14-mo-old ET-1 tg mice, } \\
\text { line } 856(n=10)\end{array}$ \\
\hline Urine sodium concentration ( $\mathrm{mmol} / \mathrm{liter})$ & $124.0 \pm 21.9$ & $135.5 \pm 37.1$ & $101.1 \pm 30.2$ \\
\hline Sodium excretion/24 h (mmol) & $0.56 \pm 0.2$ & $0.28 \pm 0.15^{*}$ & $0.47 \pm 0.15$ \\
\hline Urine potassium concentration ( $\mathrm{mmol} /$ liter) & $146.1 \pm 54.2$ & $199.9 \pm 44.1$ & $139.6 \pm 45.2$ \\
\hline Potassium excretion/24 h (mmol) & $0.65 \pm 0.2$ & $0.41 \pm 0.15$ & $0.63 \pm 0.22$ \\
\hline Urine protein concentration (g/liter) & $0.65 \pm 0.2$ & $1.05 \pm 0.7$ & $0.54 \pm 0.1$ \\
\hline Protein excretion/24 h (mg/24 h) & $2.93 \pm 0.39$ & $2.16 \pm 0.33$ & $2.51 \pm 0.50$ \\
\hline \multicolumn{4}{|l|}{ Urine protein concentration/urine creatinine } \\
\hline concentration $\left(\mathrm{mg} \times 1^{-1} / \mu \mathrm{mol} \times 1^{-1}\right)$ & $2.90 \pm 0.36$ & $3.08 \pm 0.33$ & $3.09 \pm 0.45$ \\
\hline Serum sodium concentration ( $\mathrm{mmol} /$ liter $)$ & $147.9 \pm 2.0$ & $144 \pm 4.5$ & $145.9 \pm 4.5$ \\
\hline Serum potassium concentration $(\mathrm{mmol} /$ liter $)$ & $4.8 \pm 0.3$ & $5.3 \pm 0.5$ & $5.4 \pm 0.4$ \\
\hline Serum protein concentration $(\mathrm{g} /$ liter $)$ & $64.6 \pm 2.6$ & $62.5 \pm 7.1$ & $62.4 \pm 6.5$ \\
\hline
\end{tabular}

Values are means $\pm \mathrm{SD} ;{ }^{*} P<0.05$ for $t$ test compared with age-matched controls; $\operatorname{tg}$, transgenic. 

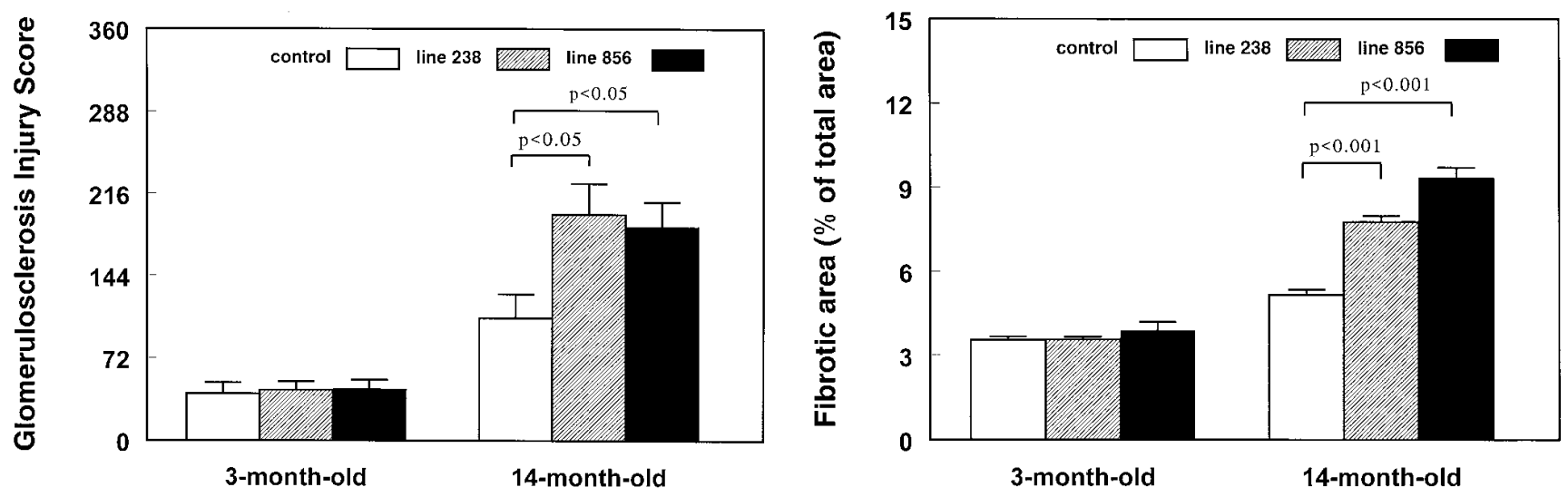

Figure 2. (A) Glomerulosclerosis in 3- and 14-mo-old heterozygous ET-1 transgenic mice (line 238, hatched bars; line 856, filled bars) and corresponding nontransgenic littermates (controls, open bars). The glomerulosclerosis injury score was determined according to Raij et al. (13), see Methods. (B) Interstital fibrosis in 3- and 14-mo-old heterozygous ET-1 transgenic mice (line 238, hatched bars; line 856, filled bars) and corresponding nontransgenic littermates (controls, open bars). Interstitial fibrosis was examined by an image analyzing system that measured the relationship of connective tissue to total interstitial area. Values are means $\pm \mathrm{SD}, n=8$ in each group.

(Figs. $2 A$ and 3) compared with age-matched controls, whereas 3-mo-old transgenic mice did not show an increased amount of PAS positive material within the glomeruli. The degree of glomerular injury was different in individual glomeruli. No significant differences in lines were observed. In addition to glomerulosclerosis, a pronounced, age-dependent interstitial (mainly peritubular) fibrosis was detected in human ET-1 transgenic mice (Figs. $2 B$ and 3). Besides glomerulosclerosis and interstitial fibrosis, we found an increased media/lumen ratio of intrarenal arteries in 3- and 14-mo-old human ET-1 transgenic mice. However, this increased ratio was only significant in the 14-mo-old mice of line 856 (Table II). Small renal cysts were seen in nontransgenic NMRI mice. The number of these cysts was about four times higher in 3- and 14-mo-old human ET-1 transgenic mice when compared with age-matched controls (Fig. 4). The number of cysts and the diameter of the individual cyst in human ET-1 transgenic mice increased with age. Other organ systems (i.e., the liver or the lungs) did not develop cysts (data not shown).

\section{Blood pressure and glomerular filtration rate}

Measurement of mean arterial blood pressure revealed no differences between 3- and 14-mo-old control mice and agematched human ET-1 transgenic mice (Fig. 5). Heart rate and systolic and diastolic blood pressure were also similar in transgenic mice and the corresponding controls (data not shown). Glomerular filtration rate, on the other hand, was significantly reduced in 14-mo-old transgenic mice (Fig. 6).

Measuring the endogenous creatinine clearance in order to analyze the glomerular filtration rate in rodents is difficult due to tubular secretion of creatinine, especially under the condition of an impaired GFR. Assuming an additional tubular secretion of creatinine in transgenic mice, the calculated GFR might be overrated. Thus, the finding of a significantly reduced GFR using the endogenous creatinine clearance method is reliable.

\section{Discussion}

In the present study, we have generated transgenic mice expressing the human ET-1 gene. Highest transgene expression was detected in the lung, brain, and kidney. The renal ET-1 overexpression induced an age-dependent development of renal cysts and renal fibrosis (glomerulosclerosis and interstitial fibrosis) without hypertension. This pronounced renal fibrosis resulted in a significantly age-dependent decreased glomerular filtration rate leading to fatal kidney disease in both transgenic mice lines.

Due to the well known nonspecific integration phenomena in transgenic animal models, only those phenotypic alterations (development of renal cysts, glomerulosclerosis, and interstitial fibrosis) are considered to be induced by the overexpression of the transgene (ET-1 in this case), which is detectable independently in different transgenic lines. It is therefore more likely that the reduced sodium excretion seen only in ET-1 transgenic mice of line 238 but not in those of line 856 is due to a nonspecific integration phenomena of the transgene and not to renal ET-1 overexpression.

Blood pressure. Blood pressure was similar in 3- and 14mo-old human ET-1 transgenic mice compared with the corresponding controls. This finding was not due to a lack of transgene expression in blood vessels as demonstrated by in situ hybridization (Fig. $1 \mathrm{~B}$ ). Instead of developing hypertension, the vascular transgene expression caused an increased lumen/ media ratio in both ET-1-transgenic mice lines. These findings are in agreement with a recent report from Schiffrin et al. (15) showing a good correlation of vascular ET-1 gene expression in deoxycorticosterone acetate and salt-treated spontaneously hypertensive rats to vascular hypertrophy, but not to hypertension. On the other hand, ET-1 infusions (3) as well as transient ET-1 gene overexpression using a replication-deficient adenoviral vector (16) have been shown to increase blood pressure. Also acute blockade of the paracrine endothelin system 

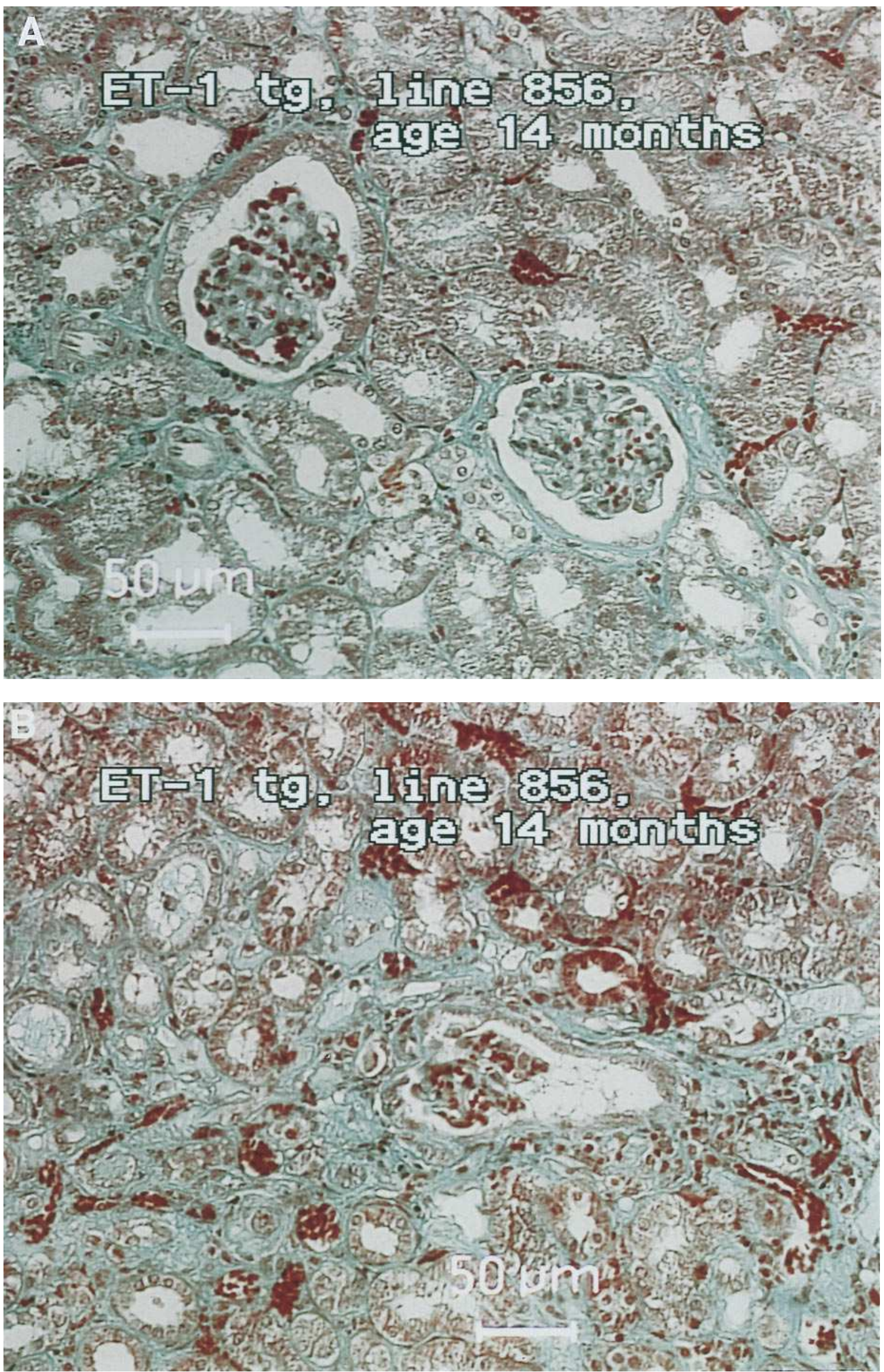

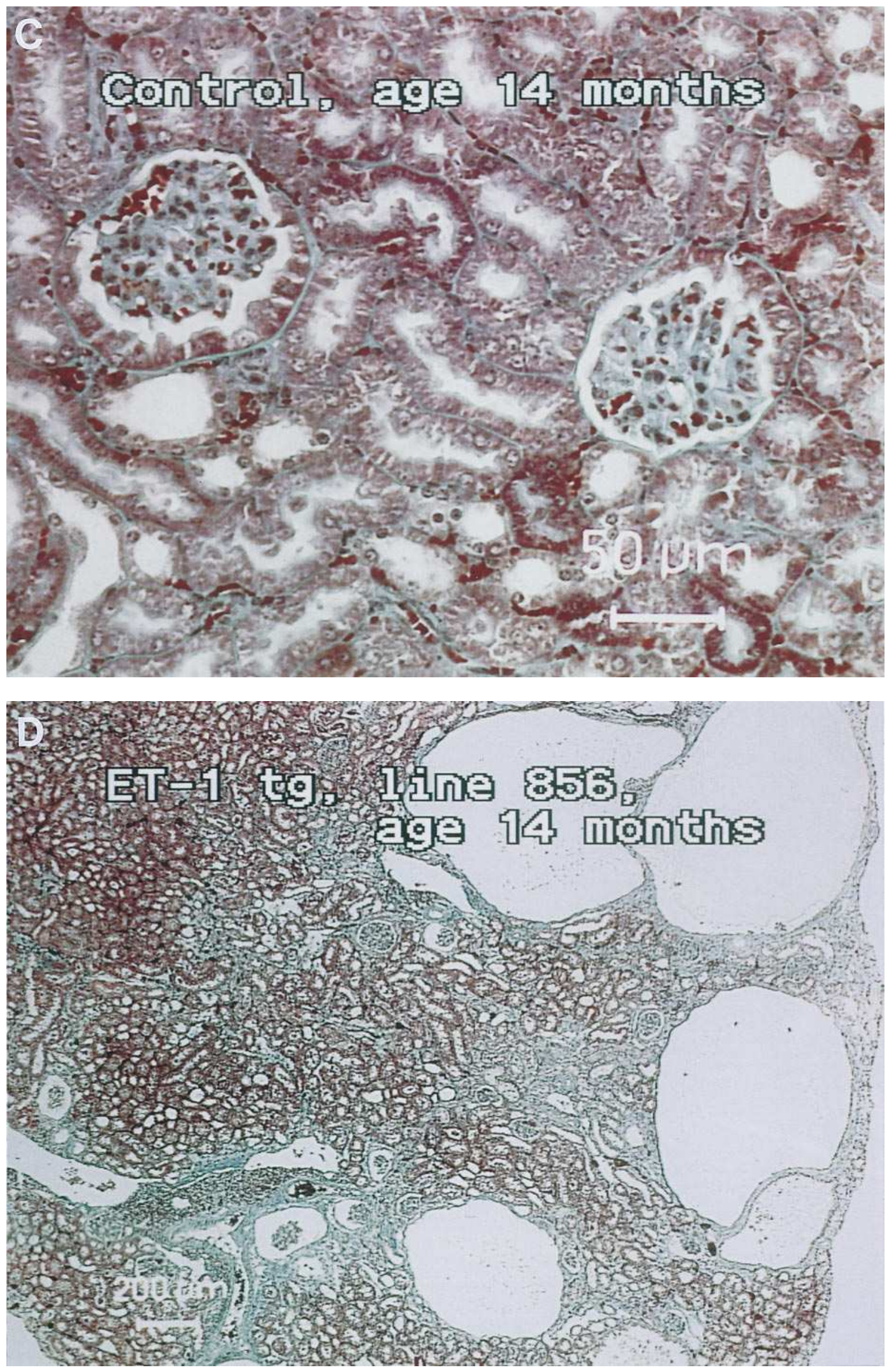


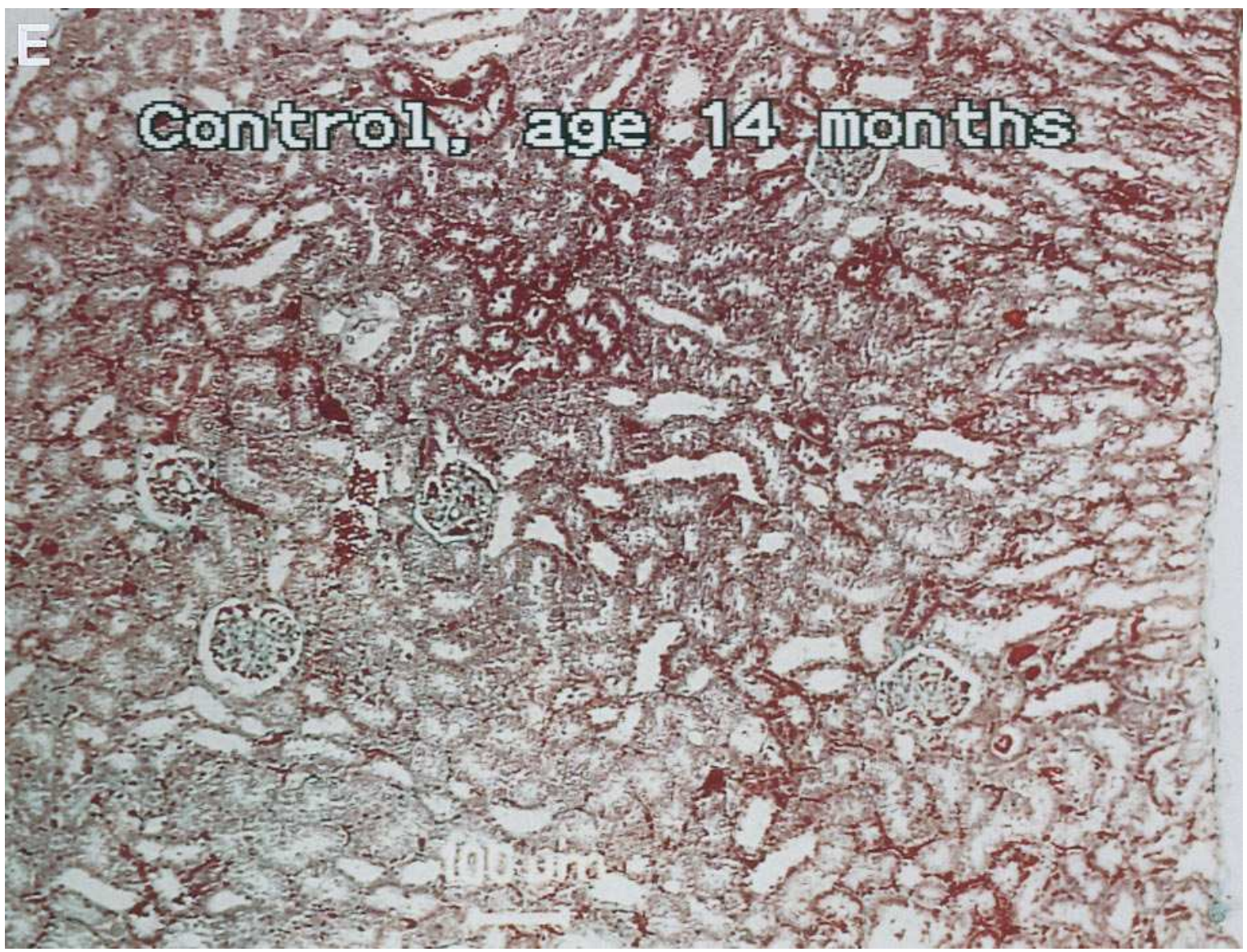

Figure 3. Sections showing typical glomeruli $(A)$ and interstitial tissue $(B)$ from a 14-mo-old human ET-1 transgenic mouse, and a corresponding nontransgenic littermate $(C)$. Note that the interstitial fibrosis is mainly seen in the peritubular space. Beside renal fibrosis, human ET-1 transgenic mice are characterized by the development of renal cysts as seen by lower magnification ( $D$, human ET-1 transgenic mouse; $E$, control). (Masson-Trichrome staining; magnification is given by calibration bars within the figures.)

in spontaneously hypertensive rats by intravenous infusions of bosentan or BQ 123 significantly decreased blood pressure (4, 17, 18). Interestingly, chronic oral treatment of spontaneously hypertensive rats with bosentan had no effect on blood pressure (19). The reasons for these seemingly contradictory findings in acute effects on blood pressure of intravenous ET-1 infusion or infusions of endothelin receptor antagonists vs. chronic overexpression of the ET-1 gene or chronic pharmacological blockade of endothelin receptors remained unclear. We assume that long-term activation or blockade of the paracrine endothelin system results in a strong activation of counterregulating mechanisms. These counterregulating mechanisms may belong to components of the paracrine endothelin system (i.e., downregulation of endothelin receptors or downregulation of postreceptor signal transduction pathways) or to nonendothelin mechanisms, such as activation of the NO system $(20,21)$.

The ET-1-induced endothelin B receptor-mediated NO synthesis leads via cGMP to a decreased synthesis of preproET-1 mRNA (22). This negative feedback mechanism of NO on prepro-ET-1 mRNA may explain the rather low ET-1 overexpression seen in ET-1 transgenic mice. In this context it is interesting that heterozygous ET-1 knock-out mice with reduced ET-1 tissue and plasma levels had a slightly elevated blood pressure (23). This unexpected finding supports the hypothesis that chronic activation of the paracrine endothelin system does not cause hypertension. In addition, the genetic background of the mouse strains used may play an important role in the development of hypertension, since it is well known that the phenotype in transgenic animals depends on both the transgene expression and the genetic background of the founder animals (24).

Development of renal cysts. Nontransgenic littermates developed small renal cysts in an age-dependent manner. Overexpression of the human ET-1 gene in the kidneys of these mice promoted this process as seen by an increased diameter of renal cysts and a highly significantly increased number of cysts in both lines of ET-1 transgenic mice. We assume that an activated renal endothelin system promoted growth and formation of renal cysts in animals with a primary, endothelin-independent genetic or environmental predisposition for developing renal cysts. ET-1 seems to be a cofactor in the pathogenesis of renal cysts requiring additional stimuli. This hypothesis is supported by the finding that endothelin-2 transgenic rats with a high renal transgene expression rate and their corresponding nontransgenic littermates (rats without genetic predisposition for renal cysts) did not develop renal cysts (B. Hocher, C. ThöneReineke, C. Bauer, unpublished observations). Despite recent advances in the determination of the genetic basis of polycystic kidney disease, little is known about the cell biology and underlying mechanisms that contribute to cyst formation in ge- 


\section{Renal cysts in ET-1 tg Mice}

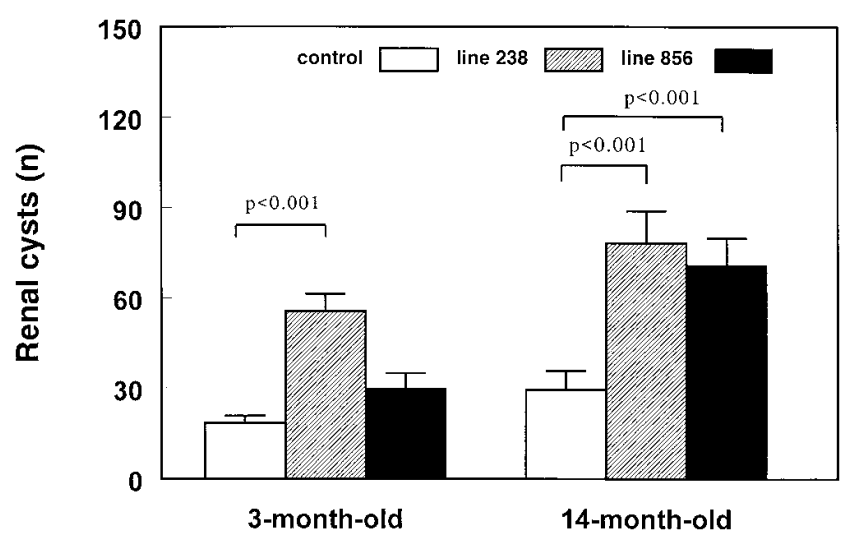

Figure 4. Number of renal cysts per kidney section in 3- and 14mo-old heterozygous ET-1 transgenic mice (line 238, hatched bars; line 856, filled bars) and corresponding nontransgenic littermates (controls, open bars). The number of renal cysts were counted in corresponding hematoxylin-eosin stained kidney cross sections. Values are means $\pm \mathrm{SD} ; n=9$ in each group.

netically or chemically induced animal models with renal cysts. Altered composition of the extracellular matrix $(25,26)$ as observed in human ET-1 transgenic mice is thought to be implicated in cystopathogenesis. In addition, abnormal renal tubular epithelial cell growth (27) seems to be involved in cystopathogenesis. Such a mechanism is also possible in ET-1 transgenic mice, since ET-1 is a well known stimulus of epithelial cell growth (1).

Interstitial fibrosis and glomerulosclerosis. Various studies have demonstrated a correlation between an activated renal endothelin system and renal injury (7-9). However, clear evidence showing that kidney ET-1 overexpression results in renal injury has been lacking. In humans, as well as in animals with kidney diseases, an activated renal endothelin system

\section{Blood pressure in human ET-1 tg Mice}

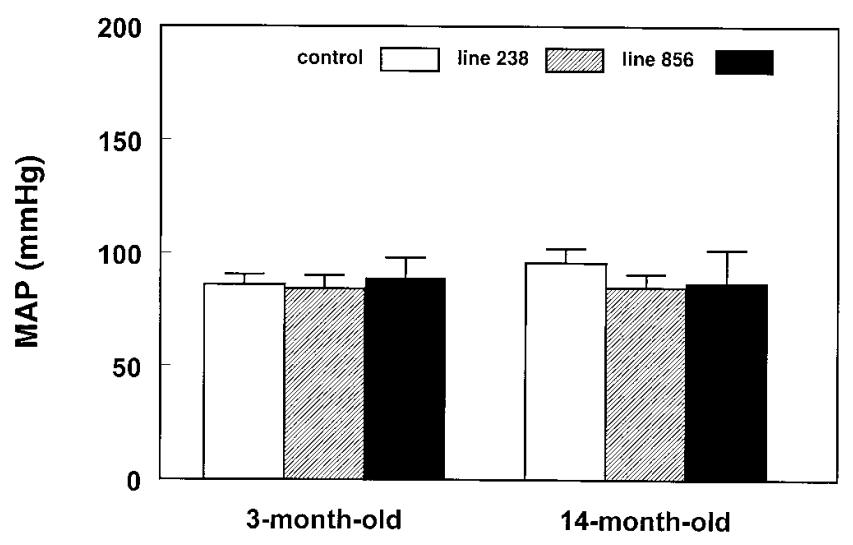

Figure 5. Mean arterial blood pressure in 3- and 14-mo-old heterozygous ET-1 transgenic mice (line 238, hatched bars; line 856, filled bars) and corresponding nontransgenic littermates (controls, open bars). Values are means $\pm \mathrm{SD} ; n=7-9$ in each group.
GFR in ET-1 $\operatorname{tg}$ Mice

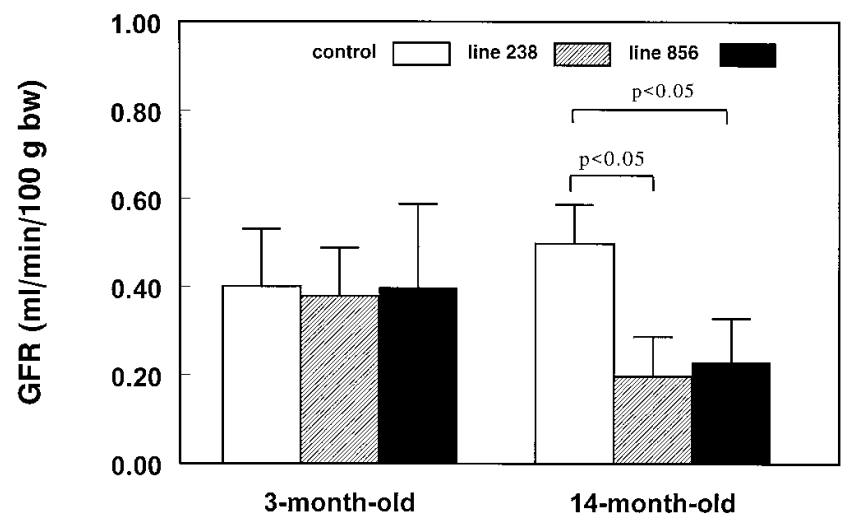

Figure 6. Glomerular filtration rate in 3- and 14-mo-old heterozygous ET-1 transgenic mice (line 238, hatched bars; line 856, filled bars) and corresponding nontransgenic littermates (controls, open bars). Values are means $\pm \mathrm{SD} ; n=7$ in each group.

(namely ET-1) due to hypoxia, renal mass reduction, cyclosporine, or inflammatory kidney diseases like lupus nephritis, seems to correlate with renal injury $(7,8,28,29)$.

Our data strongly support the hypothesis that primary overexpression of ET-1 in the kidney of transgenic mice caused an age-dependent development of a reduced glomerular filtration rate due to interstitial fibrosis and glomerulosclerosis. Several points should be addressed in this context.

First, this process was not related to systemic hypertension, since ET-1 transgenic mice were normotensive, indicating that an activated renal ET-system seems to be a blood pressureindependent risk factor for the progression of renal fibrosis to end-stage renal disease. However, alterations of the intraglomerular capillary pressure could not be excluded in our study.

Second, human ET-2 transgenic rats developing mild glomerulosclerosis without major interstitial fibrosis were characterized by a normal glomerular filtration rate (30), indicating that interstitial fibrosis as observed in ET-1 transgenic mice was an important condition for the development of a reduced glomerular filtration rate. The better correlation of kidney function with interstitial fibrosis as compared with glomerulosclerosis was observed in various human renal diseases (3133). In addition, Yamamoto et al. (14) reported that a single injection of antimesangial serum in rats resulted in a reversible glomerular injury without impairment of renal function, whereas the repeated injections of antimesangial serum caused in addition an irreversible interstitial fibrosis with sustained decrease in glomerular filtration rate.

Third, the renal tissue ET-1 concentrations in human ET-1 transgenic mice decreased with age and with the progression of renal fibrosis. This finding might be due to an age-dependent regulation of the human ET- 1 promoter activity in transgenic mice or alternatively reflect a decreased ET-1 synthesis in fibrotic tissue. In any case, renal fibrosis occurs in spite of an only moderate increase in renal tissue ET-1 concentration, indicating that early increases in ET-1 might initiate a fibrotic process that in later stages no longer requires the presence of continued elevations of ET-1.

Fourth, despite the fact that developing glomerulosclerosis and interstitial fibrosis leads to a markedly decreased glomeru- 
lar filtration rate, human ET-1 transgenic mice do not develop proteinuria. These data are in agreement with a recent report (30) showing that ET-2 transgenic rats characterized by glomerulosclerosis without interstitial fibrosis and normal glomerular filtration rate also showed no relevant proteinuria. The lack of proteinuria in these two independent animal models with a primary activated renal paracrine ET system might indicate that the ET-isopeptides themselves do not cause alterations of glomerular basement membranes usually associated with proteinuria (i.e., loss of negatively charged proteoglycans).

ET-1 growth promoting effects on glomerular cells seem to be mediated via the endothelin A receptor subtype in the kidney, since it was shown in vitro $(34)$ as well as in vivo $(28,29)$ that endothelin A receptor blockade reduces mesangial cell growth and extracellular matrix formation and improves renal function. In contrast with mesangial cells, tubular cell growth seems to be mediated via the endothelin B receptor as recently reported by Ong et al. (35).

This study demonstrated that overexpression of the entire human ET-1 gene in transgenic mice resulted in severe pathological changes within the kidney, thus corroborating reports of human patients in which an activated renal endothelin system correlated with glomerular and interstitial injury. Hence, these animals provide an interesting new experimental model to study the underlying mechanisms of ET-1-induced renal disease.

\section{Acknowledgments}

The technical assistance of S. Chotzen, C. Kropp, W. Melinat, and S. Schiller is greatly appreciated. We wish to thank Dr. F.C. Luft (Franz-Volhard-Klinik am MDC, Berlin) for helpful discussions and critical reading of the manuscript.

This study was supported by grants from the Deutsche Forschungsgemeinschaft to B. Hocher (Ho 1665/2-1) and by grants from the Forschungsfonds der Fakultät für Klinische Medizin der Universität Heidelberg to P. Rohmeiss.

\section{References}

1. Kohan, D. 1993. Endothelins in the kidney: physiology and pathophysiology. American Journal of Kidney Diseases. 22:493-510.

2. Hocher, B., R. Zart, F. Diekmann, P. Rohmeiss, A. Distler, H.-H. Neumayer, C. Bauer, and P. Gross. 1996. Paracrine renal endothelin system in rats with liver cirrhosis. Br. J. Pharmacol. 118:220-227.

3. Lüscher, T.F., B.G. Seo, and F.R. Bühler. 1993. Potential role of endothelin in hypertension. Controversy on endothelin in hypertension. Hypertension. 26:752-757.

4. Hocher, B., P. Rohmeiss, R. Zart, F. Diekmann, V. Vogt, D. Metz, M. Fakhury, K. Koppenhagen, N. Gretz, C. Bauer, H.-H. Neumayer, and A. Distler. 1996. Function and expression of endothelin receptor subtypes in the kidneys of spontaneously hypertensive rats. Cardiovasc. Res. 31:499-510.

5. Mattana, J., and R.P. Singhal. 1995. L-arginine supplementation antagonizes the effects of angiotensin II and endothelin 1 on mesangial cell proliferation. Cell. Physiol. Biochem. 5:176-192.

6. Ruiz-Ortega, M., D. Gomez-Garre, R. Alcazar, I. Palacios, C. Bustos, S. Gonzalez, J.J. Plaza, E. Gonzalez, and J. Egido. 1994. Involvement of angiotensin II and endothelin in matrix protein production and renal sclerosis. J. Hypertens. 12:S51-58.

7. Murer, L., G. Zacchello, G. Basso, A. Scarpa, G. Montini, M.L. Chiozza, and F. Zacchello. 1994. Immunohistochemical distribution of endothelin in biopsies of pediatric nephrotic syndrome. Am. J. Nephrol. 14:157-161.

8. Orisio, S. 1993. Renal endothelin gene expression is increased in remnant kidney and correlates with disease progression. Kidney Int. 43:354-358.

9. Roccatello, D., R. Mosso, M. Ferro, R. Polloni, P.G. De Filippi, G. Quattrocchio, E. Bancale, G. Cesano, L.M. Sena, and G. Piccoli. 1994. Urinary endothelin in glomerulonephritis patients with normal renal function. Clin. Nephrol. 41:323-330.
10. Bloch, K.D., S.P. Friedrich, M.E. Lee, R.L. Eddy, T.B. Shows, and T. Quertermous. 1989. Structural organization and chromosomal assignment of the gene encoding endothelin. J. Biol. Chem. 264:10851-10857.

11. Theuring, F., W. Götz, R. Balling, H.W. Korf, F. Schulze, R. Herken, and P. Gruss. 1989. Tumorigenesis and eye abnormalities in transgenic mice expressing MSV-SV40 large T-antigen. Oncogene. 5:225-232.

12. Hocher, B., R. Zart, F. Diekmann, T. Slowinski, C. Thöne-Reineke, J. Lutz, and C. Bauer. 1995. Role of the paracrine liver endothelin system in the pathogenesis of $\mathrm{CCl}_{4}$-induced liver injury. Eur. J. Pharmacol. 293:361-368.

13. Raij, L., S. Azar, and W. Keane. 1984. Mesangial immune injury, hypertension, and progressive glomerular damage in Dahl rats. Kidney Int. 26:137143.

14. Yamamoto, T., N.A. Noble, D.E. Miller, and W. Border. 1994. Sustained expression of TGF-beta1 underlies development of progressive kidney fibrosis. Kidney Int. 45:916-927.

15. Schiffrin, E.L., R. Lariviere, and J.S. Li. 1995. Deoxycorticosterone acetate plus salt induces overexpression of vascular endothelin-1 and serves vascular hypertrophy in spontaneously hypertensive rats. Hypertension (Dallas). 25: 769-773.

16. Télémaque, S., D. de Wit, and M. Yanagisawa. 1996. Elevated systemic blood pressure via adenovirus-mediated overexpression of endothelin-1 is mediated by the ETA receptors in anesthetized rats. Eur. J. Clin. Invest. 26(Suppl. 1):A47. (Abstr.)

17. Gellai, M.R., R. DeWolf, M. Pullen, and P. Nambi. 1994. Distribution and functional role of renal ET receptors subtypes in normotensive and hypertensive rats. Kidney Int. 46:1287-1294.

18. Bazil, M.K., R.W. Lappe, and R.L. Webb. 1992. Pharmacologic characterization of an endothelin A (ETA) receptor antagonist in conscious rats. $J$. Cardiovas. Pharmacol. 20:940-948.

19. Li, J.S., and E.L. Schiffrin. 1995. Effect of chronic treatment of adult spontaneously hypertensive rats with an endothelin receptor antagonist. Hypertension (Dallas). 25:495-500

20. Hirata, Y., T. Emori, S. Eguchi, K. Kanno, T. Imai, K. Ohta, and F. Marumo. 1993. Endothelin receptor subtype B mediates synthesis of nitric oxide by cultured bovine endothelial cells. J. Clin. Invest. 91:1367-1373.

21. Kohan, D.E., and E. Padilla. 1994. Endothelin-1 production by rat inner medullary collecting duct: effect of nitric oxide, cGMP, and immune cytokines. Am. J. Physiol. 266:F291-F297.

22. Moritoki, H., H. Miyano, S. Takeuchi, M. Yamaguchi, T. Hisayama, and W. Kondoh. 1993. Endothelin-3-induced relaxation of rat thoracic aorta: a role for nitric oxide formation. Br. J. Pharmacol. 108:1125-1130.

23. Kurihara, Y., H. Kurihara, H. Suzuki, T. Kodama, K. Maemura, R. Nagal, H. Oda, T. Kuwaki, W.H. Cao, N. Kamada, et al. 1994. Elevated blood pressure and craniofacial abnormalities in mice deficient in endothelin-1. $\mathrm{Na}$ ture (Lond.). 368:703-710.

24. Sibilia, M., and E.F. Wagner. 1995. Strain-dependent epithelial defects in mice lacking the EGF-receptor. Science (Wash. DC). 269:234-238.

25. Schäfer, K., M. Bader, N. Gretz, I. Oberbäumer, and S. Bachmann. 1994. Focal overexpression of collagen 4 characterizes the initiation of epithelial changes in polycystic kidney disease. Exp. Nephrol. 2:190-195.

26. Carone, F.A., R.J. Butkowski, S. Nakamura, M. Polenakovic, and Y.S. Kanwar. 1994. Tubular basement membrane changes during induction and regression of drug-induced polycystic kidney disease. Kidney Int. 46:1368-1374.

27. Carone, F.A., R. Bacallao, and Y.S. Kanwar. 1995. The pathogenesis of polycystic kidney disease. Histol. Histopathol. 10:213-221.

28. Benigni, A., C. Zoja, D. Corna, S. Orisio, L. Longaretti, T. Bertani, and G. Remuzzi. 1993. A specific endothelin subtype A receptor antagonist protects against injury in renal disease progression. Kidney Int. 44:440-444.

29. Nakamura, T., Y. Ebihara, Y. Tomino, and H. Koide. 1995. Effect of a specific endothelin A receptor antagonist on murine lupus nephritis. Kidney Int. 47:481-489.

30. Hocher, B., L. Liefeldt, C. Thöne-Reineke, H.-D. Orzekowski, A. Distler, C. Bauer, and M. Paul. 1996. Characterization of the renal phenotype of transgenic rats expressing the human endothelin-2 gene. Hypertension (Dallas). 28:196-201.

31. Nath, K.A. 1992. Tubulointerstitial changes as a major determinant in the progression of renal damage. Am. J. Kidney Dis. 20:1-17.

32. Riston, R.A., J.C. Sloper, and H.E. de Wardener. 1968. Relationship between renal function and histological changes found in renal-biopsy specimens from patients with persistent glomerular nephritis. Lancet. ii:363-366.

33. Wehrmann, M., A. Bohle, O. Bogenschütz, R. Eissrle, A. Freislederer, C. Öhlschlegel, G. Schumm, C. Batz, and H.V. Gärtner. 1989. Long-term progression of chronic idiopathic membranous glomerulonephritis. An analysis of 334 cases with particular regard to tubulo-interstitial changes. Clin. Nephrol. 31: 67-76.

34. Nassar, G.M., and K.F. Badr. 1994. Endothelin in kidney disease. Cur. Opin. Nephrol. Hypertens. 31:86-91.

35. Ong, A.C.M., T.P. Jowett, J.D. Firth, S. Burton, F.E. Karet, and L.G. Fine. 1995. An endothelin-1 mediated autocrine growth loop involved in human renal tubular regeneration. Kidney Int. 48:390-401. 